\title{
The Implementation of Mental Training Method in Sport to Increase Athlete's Mentality at Student Education and Exercise (PPLP) Makassar
}

\author{
Eva Meizara Puspita Dewi, Saharullah \& Hasyim \\ Universitas Negeri Makassar \\ evabasti@yahoo.com
}

\begin{abstract}
The development of employees of the State Civil Apparatus (ASN) with integrity, professional, neutral, clean and able to provide public services for the public is important one of which can be optimized through human capital. Based on previous research on the role of Human Capital on the establishment of Climate Services which ultimately affect the Service Performance Public, known image of employee ASN Municipal Government (City Government) B at staff level and kasubag only half have Human Capital is high enough. Emotional Capital is the most contributing dimension to Human Capital but its Secial Capital dimension is low then Human Capital optimization on ASN employees should be pursued by psychological intervention, the method of Employee Coaching \& Counseling Program (ECCP) in group. This study is an action research with experimental approach of one group pretest- posttest design. The results of the study show the ECCP method is quite effective, contributing to the improvement of Human Capital, especially the significant increase in the Emotional Capital dimension.
\end{abstract}

Keywords: Employee coaching\& counseling program, human capital, pegawai ASN

\section{PREFACE}

Sport coaching in the present has been much improved. This is due, among other things, to the role of various sciences such as anatomy, physiology, biomechanics, psychology, nutrition, and sport health. The mutual has a relationship between science with one another, so it can solve the problems that occur especially during practice and competition. The achievements of today's national achievements have been tackled by sports experts, both at the regional and national levels of various disciplines. The combination of human physical science with psychics science makes understanding of humans more complex. Many practice methods are a direct contribution from the world of sports psychologists (Main, 2008). Furthermore, Weingberg and Goul (1995, in HIMPSI, 2008) suggest that psychology exercise has basic objectives: (1) studying how psychological factors affect individual physical performance, and (2) understanding how participation in sport and exercise influences individual development including health and wellbeing. To be able to understand the state and mental development of the athletes absolutely it needs an individual approach as a unified whole that includes: physical and psychological aspects, as well as social beings and God's creatures. Kleinman in Sudibyo Setyobroto (2001: 13) emphasized the absolute need of a holistic approach or "wholistic-approach" of sports achievement is not sufficiently somatic, because the increase or decrease of the athletes' performance is determined by psychological factors.

Sport achievement is determined not only by physical elements, techniques and strategies, but also by mental aspects. To gain a high level of sport achievements, all aspects are needed to make athletes achieve optimum achievements and become a champion. Then, in addition to various exercises, it also requires mental training programs which are general or special, adjusted with various conditions of the athletes. To improve their performance, the athletes need to have a strong mentality, so they can practice and compete with high spirits, total dedication, never give up, and are not easily distracted by non-technical and personal problems. Thus, they can run their training program well. In the end, they can have excellent physical, high technique, and appropriate matching strategy, according to the training program designed by the trainer. Thus, it appears that mental exercise aims to make the athletes achieve peak performance, or a better achievement than ever.
Any changes in the behaviors, feelings or thoughts of an athlete disturbing them which can interfere the training or communication problems between them and the others, is one indication that the athlete is experiencing dysfunction or psychological problems. However, before making sure that the problem is caused by psychological factors, it is necessary to carefully analyse the possible causes of technical or physiological factors. If the main cause which is a technical or physical factor is not handled properly, the factors that need to be addressed first, psychological mental problems, will be difficult to overcome.

PPLP Makassar, in South Sulawesi, develops 9 sports; football, boxing, rowing, athletics, takraw, martial arts, karate, taekwondo, and volleyball. There are 85 athletes who are currently in training. At PPLP Makassar, the training program has been running well but one that is still lacking is a mental training program that has not been effectively executed so that this research tries to apply and test the effectiveness of the mental enhancement of the athletes after this training.

\section{RESEARCH METHOD}

This study is in the form of classroom action research. Action research is a reflective study to improve the rational ability of the participants' actions in carrying out their tasks, deepening their understanding of the actions they perform, and improving the conditions in which certain learning or training practices are conducted. The technique of collecting the data is observation of the athletes' activity and assessment test using questionnaire result of mental exercise which consists of three aspects; progressive relaxation, concentration training and imagery exercise. The data analysis technique used in this research is descriptive quantitative with percentages.

According Arikunto (2012: 16) there are four stages that are commonly passed in the process of action research, namely: a. Action planning, b. Implementation of the action, c. Observation or observation, d. Reflection. This study is designed to be implemented in a recycling cycle as shown in the following figure: 


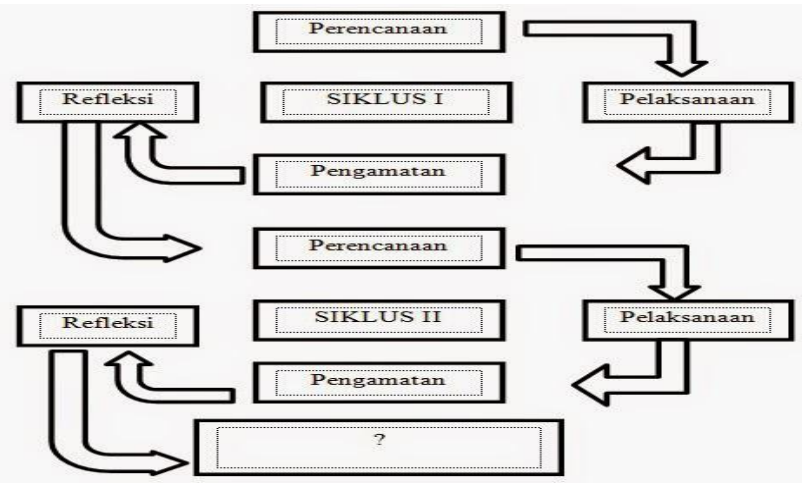

RESULT AND DISCUSSION

\section{Result}

After the implementation of progressive relaxation training method, cycle I showed that the athletes who strongly agree are $11.18 \%$, agree $72.94 \%$, hesitate $15.88 \%$, disagree $0 \%$ and strongly disagree $0 \%$. Thus, it can be concluded that the athletes of PPLP Makassar with progressive relaxation exercise can be categorized either $72.94 \%$ or cumulatively equal to $84.12 \%(72.94 \%+11.18 \%=84.12 \%)$.

After the implementation of training method, cycle I showed that the athletes who strongly agree are $2.35 \%$, agree $18.82 \%$, hesitate $43.53 \%$, disagree $29.41 \%$ and strongly disagree $5.88 \%$. It can be concluded that the athletes of PPLP Makassar who gets training can be considered quite convinced with the method because the value of hesitancy regarding the practice of the method to get the highest score is $43.53 \%$. It still needs to be done in the exercise in cycle II because the exercises are in enough category.

After the implementation of imagery model, cycle I showed that the athletes who strongly agree are $6.47 \%$, agree $69.41 \%$, hesitate $22.94 \%$, disagree $1.18 \%$ and strongly disagree $0 \%$. Therefore, it can be concluded that the athletes of PPLP Makassar with imagery exercise can be considered to get the highest value or equal to $69.41 \%$ or cumulatively equal to $75.88 \%(69.41 \%+6.47 \%=75.88 \%)$.

The observation result on exercise in cycle 1 is the description of the athletes' attitude during the training activity in every cycle I meeting: (a) The focus of listening in the athletes's mental training method in the first cycle is $72.94 \%$ and those who are less focused are $27, .06 \%$. This indicates that the mental training method is better, (b) The questioner's diligence in the process of mental training method on the athletes of PPLP Makassar cycle I is equal to $21.18 \%$ and those which have less question and answer are equal to $78.82 \%$. This indicates that the process of mental training on the athletes is still lacking. It needs to be done again in the exercise in cycle II, (c) The confidence in the mental training process on the athletes in cycle I is $75.88 \%$ and those who are less confident are $24.12 \%$. This indicates that the aspect of mental training methods is better.

The result of observation of training in cycle II is a description of the activeness of the question and answer aspects in following the mental training process on the athletes in every cycle II meeeting. The athletes who are responsible for doing mental exercises in cycle II is $90.88 \%$ and those who are less are $9.12 \%$. This indicates that the process of mental exercise is very good. The recapitulation of observation derives from cycle I to cycle II, the third aspect of the athletes' activity is $79.9 \%$ and those which are less are $20.11 \%$ during the following mental training process.

After the implementation of training method, cycle II shows that the athletes who strongly agree are $12.35 \%$, agree $78.53 \%$, hesitate $9.12 \%$, disagree $0 \%$ and strongly disagree
$0 \%$. Thus, it can be concluded that the athletes at PPLP Makassar with training can be categorized with the highest value which is equal to $78.53 \%$ or cumulatively equal to $90.88 \%(78.53 \%+12.35 \%=90.88 \%)$.

From the data recapitulation from the result of mental training method, cycle I and cycle II show that the athletes who strongly agree are $10 \%$, agree $73.63 \%$, hesitate $15.98 \%$, disagree $0 \%$ and strongly disagree $0 \%$. Thus, it can be concluded that the athletes of PPLP Makassar in following mental training can be categorized with the highest score which is equal to $73.63 \%$ or cumulatively equal to $83.63 \%$ $(673.63 \%+10 \%=83.63 \%)$.

\section{DISCUSSION}

Based on the results of quantitative analysis with percentage analysis approach that has been stated previously, then the following describes the study of research which is also the answer of the formulation of the problem as well as discussing the results of questionnaires and observation research.

Described in the pre-cycle percentage stage of completeness of mental exercise of the athletes of PPLP Makassar in cycle I, it is obtained the value of $84.12 \%$ for the aspects of the method of progressive relaxation exercise, $21.1 \%$ for the aspect of the method of concentration exercise, and $75.88 \%$ for the aspects of imagery practice method. For the first cycle, there is one aspect that has not been completed that is on the aspect of the method of concentration training. The aspects of the activity of the athletes that have not completed the first cycle is diligent question and answer and it is obtained by $21.18 \%$ and those which have less question and answer are $78.82 \%$.

In the aspect of concentration exercise, it is given treatment again in cycle II. After giving the treatment, the questionnaire results can be stated that in this cycle II it is obtained the value of $90.88 \%$ for the aspects of the method of concentration training. On the observation of the athletes' activity of diligent aspect, it increased by $90.88 \%$ and less by $9.12 \%$. Thus, this proves that the application of mental training methods in sport at PPLP Makassar has positive influence to improve the mentality of the athletes at PPLP Makassar. The observations from cycle I to cycle II are the three aspects of the athletes's activity which are $79.9 \%$ and those which are less are $20.11 \%$ during the mental training process.

An overview of the application of mental training methods on the athletes of PPLP Makassar from cycle I to cycle II shows that the athletes who strongly agree are $10 \%$, agree $73.63 \%$, hesitate $15.98 \%$, disagree $0 \%$ and strongly disagree $0 \%$. Thus, it can be concluded that the athletes of PPLP Makassar in following mental training can be categorized to get the highest score or equal to $73.63 \%$ or cumulatively equal to $83.63 \%(673.63 \%+10 \%=83.63 \%)$ and the general description of the athletes' activity during mental training has increased the activity of the athletes to $79.9 \%$ and less $20.11 \%$.

Based on the discussion in the application of the method of mental training in sport at PPLP Makassar, it aims to determine the mental enhancement of the athletes and develop reasoning, traits, and motivations which are done systematically and well planned. It also aims to diagnose the state and development of the athletes' psychology to determine their ability or talent and weaknesses, so that the treatment given can really fit their situation. In the end, the athletes need to improve their performance. Sport achievement is determined not only by physical elements, techniques, and strategies, but also the mental aspects. This is 
stated by Komarudin (2016: 7) that the athletes must have multiple abilities that is not only physical ability but also mental ability, because mental ability will form consistency in the athletes in reaching their peak performance.

To achieve high sport achievement, then all the aspects are needed to make the athletes achieve their peak performance and become a champion. Therefore, in addition to the various exercises, mental rehearsal programs are required both in general and specifically which are adjusted with various conditions of the athletes.

It is also important to develop common and dominant mind sets while nurturing courage and fun in practice. At PPLP Makassar, many athletes are quite potential, but can't be superior. One cause is because they feel not confident with their own ability. Many athletes who fail in the training process not because they do not have the ability, but because they are not confident with the potential they have. As stated by Husdarta (2010: 92) that confidence is one of the main and absolute requirements to achieve a brilliant achievement in sport.

It should be reiterated that positive thoughts will be able to shape and strengthen the athletes' personality character. So, for the athletes who always think positively, they will be more mature and do not have to worry and doubt about the abilities that other athletes have. The important thing is the athletes must have a habit to always think positively by looking at their abilities and potential and believe that they will be able to do great things.

The athletes who have achieved their great ideals become famous until now. Without thinking that the athletes have no weaknesses, the athletes are the people who take the advantage of weaknesses and lacking into strength. Based on the results of this study, it can be argued that the application of mental training methods in which there are three aspects; progressive relaxation aspect, concentration and imagery, provide the role of motivation on a very large exercise and achievement

\section{CONCLUSION}

Classroom Action Research on Makassar PPLP athletes is conducted in two cycles and each cycle consists of four stages: (1) planning, (2) action implementation, (3) observation and interpretation, and (4) analysis and reflection. Based on the data analysis that has been done, it can be concluded that:

From the analysis result, it is obtained significant improvement from cycle I and cycle II. The result of mental training in cycle $\mathrm{I}$ is there is one aspect that is not yet complete that is on the aspect of concentration training and the activity aspect of the athlete's answer, Meanwhile, the aspect of the progressive relaxation training method and the imagery exercise method in the finished category or in the good category are $84.12 \%$ and $75.88 \%$, while for practice method of concentration it got the value which is equal to $21.18 \%$. The practice of the concentration is not completed and needs to be done in further treatment in cycle II. In other words, the method of concentration training needs to be conducted in further research. Furthermore, in cycle II, there is an increase of percentage of mental exercise result in good category which is equal to $83.63 \%$. Especially in the aspect of concentration practice method, there is an increase of $90.88 \%$, also the activity aspect of the athletes in cycle II is equal to $90.88 \%$ and less equal to $9.12 \%$ or overall indicators are in good category.

The overall implementation of mental training method in sport at PPLP Makassar in cycle I obtained cumulative value of $60.39 \%$ while for cycle II it increased to $83.63 \%$. Thus, the application of mental training methods on the athletes of
PPLP Makassar is needed to improve mental exercise to achieve some achievements

\section{SUGGESTIONS}

Based on the research results, it can be suggested some things, especially for the trainers at PPLP Makassar, as follows:

1. The trainers should be more innovative in applying methods to deliver mental exercise materials;

2. For the athletes' mental training, it should be done repeatedly; therefore it takes time, effort, and feedback for the progress of an exercise. Mental exercise can be done where and whenever it is applicable;

3. The trainers should provide a simple, efficient, effective, and cost-effective method of training to make it visible and can be done directly by the athletes. It can also motivate the athletes to constantly try and repeat the mental training exercises.

\section{REFERENCES}

Arikunto, Suharsimi. 1993. Prosedur Penelitian; suatu Pendekatan Praktek. Jakarta :Rineka Cipta Press.

Arikunto, Suharsimi. 2012. Penelitian Tindakan Kelas. Jakarta: PT Bumi Aksara.

Dantes, Nyoman. 2012. Metode Penelitian. Yogyakarta: CV Andi.

Gunarsa, Singgih D. 2004.Psikologi Olahraga Prestasi. Jakarta : BPK Gunung Mulia

Gunarsa, singgih D. 1996. Psikologi Olahraga. Teori dan Praktek. Jakarta : BPK Gunung Mulia

Harsono. 1988. Choaching dan Aspek-aspek Psikologi dalam Coaching. Jakarta :Tambak Kusuma

Husdarta. 2010. Psikologi Olahraga. Bandung: Alfa Beta.

Komarudin. 2015. Psikologi Olahraga, Latihan Keterampilan Mental dalam Olahraga Kompetitif. Bandung: PT. Remaja Rosdakarya.

Mulyana, 2006. PsikologiOlahraga, Served on TOT Young Coach, Solo 11-14 September 2006

Mylsidayu Apta, 2015. Psikologi Olahraga. Jakarta: PT. Bumi Aksara

Nasution, Yuanita. Psikologi Olahraga Teori dan Praktek: Model Program Latihan Mental Bagi Atlet. Jakarta: PT. BPK Gunung Mulya.

Satiadarma, Monthy P. 2000. Dasar-DasarPsikologi Olahraga. Jakarta :Pustaka Sinar Harapan.

Sugiyono, Statistik untuk Penelitian. Bandung: Alfabeta, 2010.

Setyobroto, Sudibyo. 2001. Mental Trainin g. Jakarta: "Percetakan Solo". 